\title{
Reliability tests in the operation of military vehicles
}

\author{
Kamil PRZYBYSZ *1 \\ ${ }^{1}$ Military University of Aviation, Aeronautics Faculty, Dęblin, Poland
}

\begin{abstract}
Reliability studies in the operation of military vehicles are not carried out extensively. This is due to the guidelines of superiors regarding the keeping of operational records in military units. As a result, this work attempts to determine the reliability of military vehicles. This work includes reliability tests of military vehicles operated in military units in the second phase of operation, i.e. in the operation interval, where the extent of change in the intensity of damage is the least in the function of mileage. The study used a sample of 37 vehicles for which all operational events relevant to reliability determination were recorded during a two-year observation period. Using recorded operational data, an empirical reliability function of the vehicles included in the test sample was determined. Based on reliability tests of the reliability function as a function of mileage to damage, they show that second-phase vehicles used in military units have a logarithmic distribution of reliability as a function of mileage.
\end{abstract}

Keywords: reliability, operation, military vehicles.

\section{Introduction}

Research and development works regarding modern military vehicles should primarily be aimed at shaping an adequate level of dependability of military vehicles, as one of the key factors for success in the mission, as highlighted at work [6]. Dependability will be shaped by the two main factors mentioned in [7] "i.e.:

- the state of technical suitability at any time, referred to as "availability" and expressed as an indicator of the probability that the facility is technically suitable for action,

- the state of technical suitability during the task undertaken, referred to as reliability, and expressed as a reliability indicator as the probability of performing the task undertaken."

In recent years, greater attention in the military to research into readiness and reliability has been attached to aeronautical technology. Presented in works [2, 3, 8-11] methods for determining the reliability forecast of aircraft, including signalized and emergency damage, make it possible to estimate their durability and ensure a more efficient use of the maintenance strategy according to the technical condition that is widely used for aircraft.

For military vehicles, readiness and reliability studies have not been conducted to such a wide extent as aircraft. The main reason for this is the lack of basic data with regard to the damage to vehicles operated in military units. The guidelines for keeping operational records for military vehicles do not take into account reliability analyses, the knowledge of which is paramount importance for shaping effective operation and dependability. Analyzing the processes of operation of military motor vehicles at work [5] it was concluded that, first of all, it is necessary to invest in the operating system, which is the basis for maintaining high reliability.

The control of the operation of military vehicles is closely correlated with the requirements for maintaining an adequate level of combat readiness by the Armed Forces and thus individual military units. The requirements imposed regarding the level of technical efficiency, vehicles equipped with military units, force the commanders of the various levels of command and other decision-makers of the logistics system, e.g. Central Logistics Bodies (cell or organizational unit of the Ministry of National Defense, as well as the internal cell, responsible for determining (standardizing) operating processes and training technical specialists for specific types (groups) of military weapons and equipment - UiSW [1]), adapting the general strategic objectives to the conditions. These conditions will be determined by the imposed level of combat readiness and the allocated limit of funds for the maintenance of the military technology.

*corresponding author: E-mail address: (k.przybysz@law.mil.pl) Kamil PRZYBYSZ 
Reliability testing is important not only in terms of maintaining and shaping the readiness of military vehicles, but also needed to control the operation process, make optimal operational decisions. Knowledge of the distribution of damage allows not only to determine the weak elements of the technical facility, but also to plan the appropriate service system and the level of maintenance of spare parts.

\section{Selection of the test sample and accepted test methodology}

Reliability testing was carried out on a sample of Jelcz vehicles of different types: S662 - D.43, P662 variants D.34 and D.43, C642 D.35, P862 D.43 operated on a daily basis in a military unit, i.e. under real-world operating conditions typical of military vehicles. This sample represents 37 vehicles in the second phase of operation, i.e. during normal wear and tear. The average mileage per year for the vehicle included in this sample was $10777 \mathrm{~km}$, reflecting the level of average mileage of these types of vehicles in the general population, operated in military units.

The observation period for the sampled vehicles was two years. On the basis of an analysis of the operational documentation collected, the following information was established for each vehicle in the test:

- identification data: brand and type, registration number,

- year of manufacture,

- date of commencement and completion of the tests,

- dates of departures and returns (number of departures),

- mileage per year expressed in $\mathrm{km}$,

- the initial and final counter states on each exit,

- counter states in case of damage and operation (number of $\mathrm{km}$ travelled for damage or operation),

- the dates of all damage, broken down by damage during operation and damage caused in a state of waiting for work,

- dates of all service,

- the extent of the individual repairs resulting from the damage.

Using the data of the sample described above by means of nonparametric methods, the empirical reliability function of the vehicles included in the sample was determinedaccording to the following formula [4]:

$$
R^{*}(s)=\frac{n-m(s)}{n}
$$

where:

$\mathrm{n}$ - sample count,

$\mathrm{m}(\mathrm{s})$ - number of failed vehicles before reaching the mileage $\mathrm{s}$ (excluding the moment when this mileage is reached),

$\mathrm{n}-\mathrm{m}(\mathrm{s})$ - number of vehicles without failures until the mileage $\mathrm{s}$ is reached.

Similarly, the function of failure, i.e. the empirical distributionF(s) of the random variable $\mathrm{S}$ (vehicle mileage to the first damage) is designated according to the following formula [4]:

$$
F^{*}(s)=\frac{m(s)}{n}
$$

where:

$\mathrm{n}$ - sample count,

$\mathrm{m}(\mathrm{s})$ - number of failed vehicles before reaching the mileage $\mathrm{s}$ (excluding the moment when this mileage is reached),

Probability density of mileage length to damage vehicle $\mathrm{f}(\mathrm{s})$ from formula [4]: 


$$
f^{*}(s)=\frac{m(s, s+\Delta s)}{n}
$$

where:

$\mathrm{m}(\mathrm{s}, \mathrm{s}+\Delta \mathrm{s})-$ number of vehicles that have been damaged in the mileage interval $(\mathrm{s}, \mathrm{s}+\Delta \mathrm{s})$.

Intensity of vehicle damage $\lambda^{*}(s)$ by paradigm $([4]$ :

$$
\lambda^{*}(s)=\frac{n(s)-n(s+\Delta s)}{n(s) \cdot \Delta s}=\frac{m(\Delta S i)}{n(s) \cdot \Delta s}
$$

where:

$n(s)$ - number of undamaged vehicles until mileage is reached $s$,

$\mathrm{n}(\mathrm{s}+\Delta \mathrm{s})$ - number of undamaged vehicles until mileage is reached $(\mathrm{s}+\Delta \mathrm{s})$,

$\mathrm{m}(\Delta \mathrm{si})$ - number of vehicles that have been damaged in thei-th mileage subinterval $\Delta$ si.

Leading distribution function according to the following formula [4] :

$$
\Lambda^{*}(s)=\sum_{k}^{m}=1 \frac{1}{n-k+1}
$$

where:

$\mathrm{n}$ - sample count,

$\mathrm{k}$ - the next number of damage in the test corresponding to the next mi(s), i.e. the number of vehicles damaged until the mileage is reached.

Using the calculated values of the empirically determined functions described above, graphs shall be drawn up. When analyzing the course of the characteristics drawn up, a hypothesis must be formulated as to the distribution of the correct working time of the vehicle, expressed in mileage units - s, at a certain level of significance $\alpha$. The validity of the hypothesis as to the distribution of the S-trait to be tested should be examined using the test algorithm for the assumed distribution. By approximating the empirical reliability characteristics of a specific typical probability distribution, other functional and numerical characteristics can be determined according to the defined dependencies for a given distribution type.

\section{Analysis of test results}

The obtained reliability characteristics presented in Figure 1 as a result of the tests shown above proves that secondphase vehicles used in military units have a logarithmic distribution of reliability as a function of mileage.

The maintenance time of the vehicle in technical suitability was recorded during the tests by the amount of mileage between the damage, estimated in kilometers, so the argument of the reliability function is the mileage s, expressed in $\mathrm{km}$, and not in units of time. The above function can be approximated by the logarithmic function to the following:

$$
R(s)=0.199 \ln (s)+0.808
$$

When analyzing the distribution of the designated unreliable function shown in Figure 2, it is easy to see that, for mileage less than $10000 \mathrm{~km}$, the probability of failure increases rapidly, after which it is set at 0.703 in the range (10 000, 18 000), after which it rises again and is set to 0.838 in the high mileage range $(20000,60000)$.

The course of an empirically designated function of unreliableness, as in the case of reliability functions, can be approximated by a logarithmic function:

$$
R(s)=0.199 \ln (s)+0.192
$$


R(s)

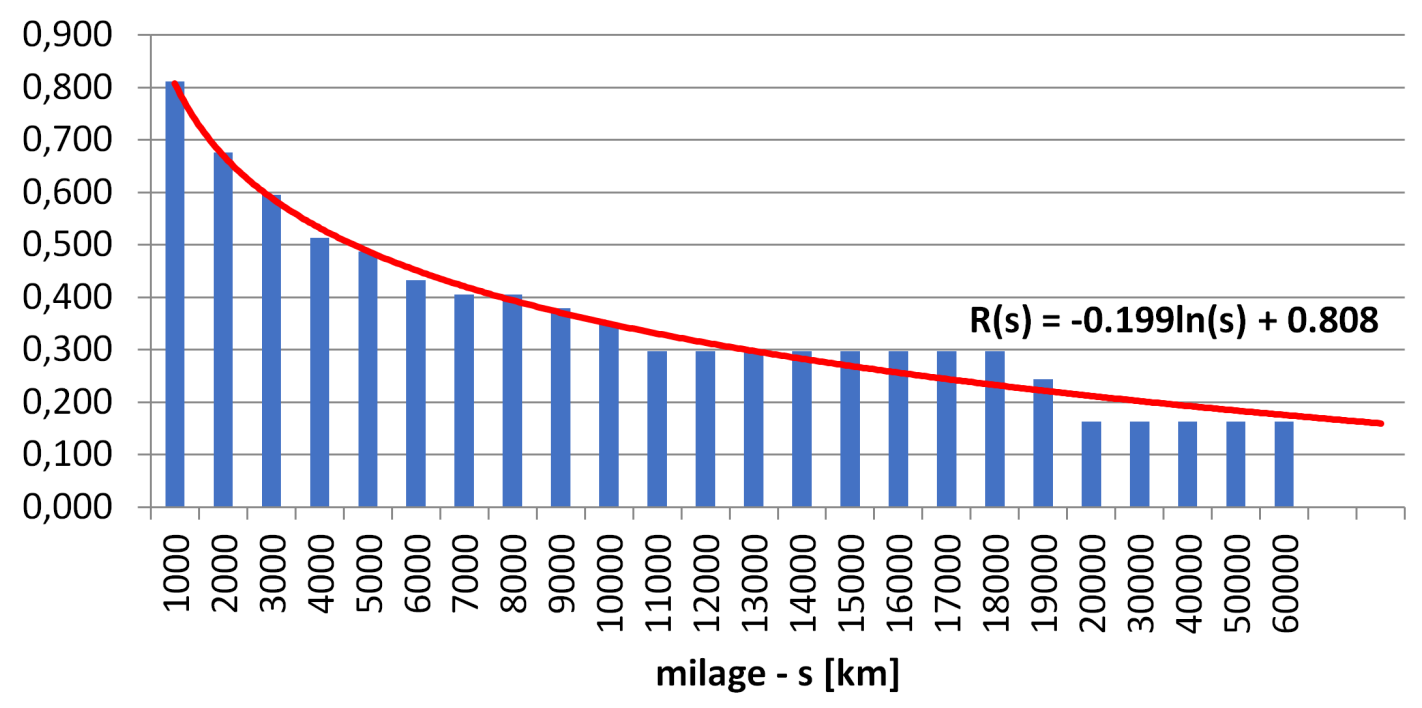

Figure 1. Experiential reliability function of military vehicles
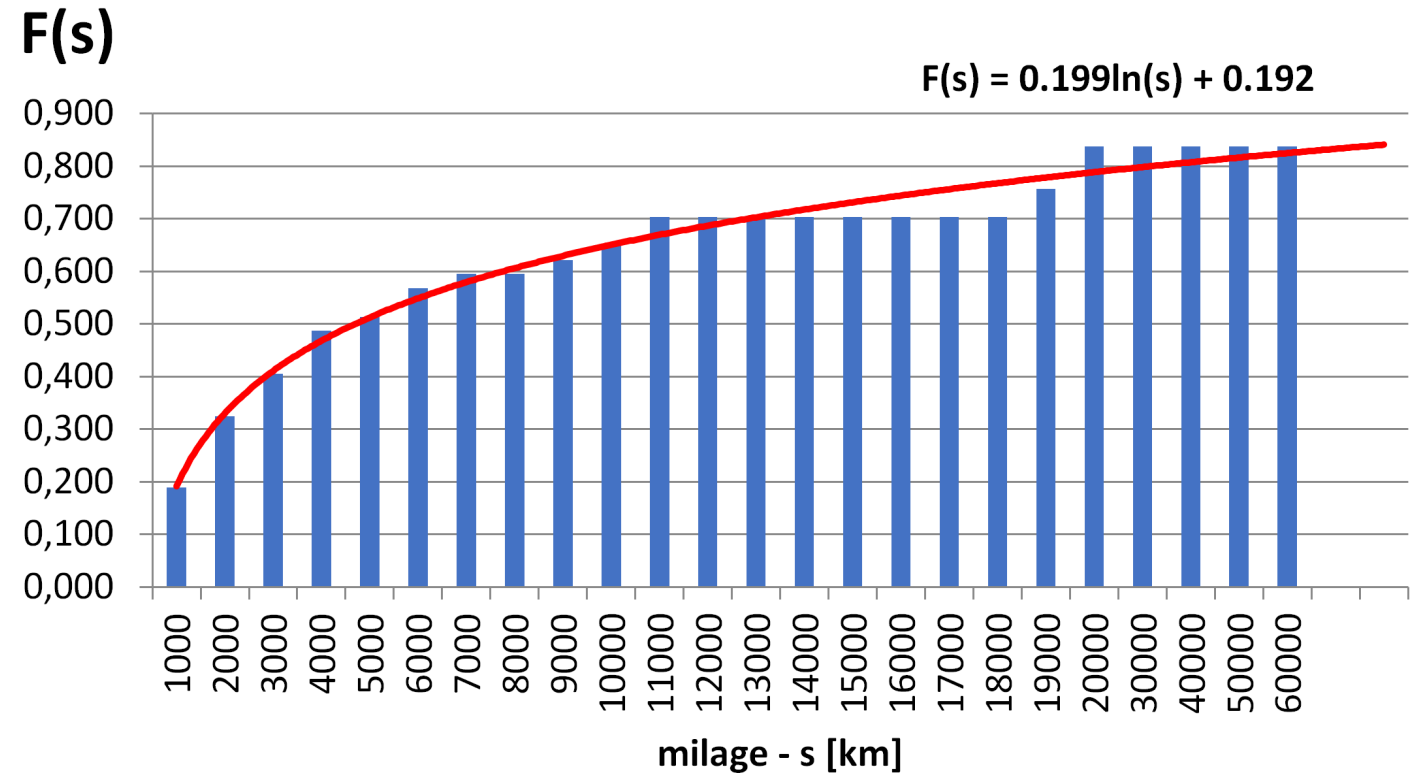

Figure 2. Random variable distribution s for military vehicles

\section{Conclusions}

The results of the reliability tests carried out for the exposed vehicle test show that the fastest increase in unreliability, i.e. the likelihood of damage, is to be expected for a mileage of less than $10000 \mathrm{~km}$ from the moment when the vehicle was in full technical suitability. In the range $(10000 ; 18000) \mathrm{km}$ of mileage, the unreliability is very high (0.703), but remains at the same level. It is only with significant runs, more than $20000 \mathrm{~km}$, that there is a further increase in unreliability.

Based on reliability tests of the reliability function in the mileage-to-damage function, military vehicles from the second phase of operation have a high level of dependability for single tasks that do not require high mileage. The level of dependability will logarithmically decrease when performing tasks requiring more mileage, or when carrying out a series of operational tasks with significant mileage, where it will not be possible to restore the technical suitability 
between the implementation of individual operational tasks.

This work includes tests of the reliability of military vehicles in the second phase of operation, where the extent of changes in the intensity of damage is the least in the function of mileage. Further research should include research into readiness and reliability of military vehicles from the first phase of operation (newly put into service in military units) for which the damage intensity according to theory should be at a much higher level. Military vehicles from the first phase of operation make up a smaller part of the technical equipment parks of military units, but these studies are particularly reasonable in terms of creating a new strategy of operation, based on the results of research for these vehicles.

A key element influencing the effectiveness of the research conducted on the reliability of military vehicles is the creation of an appropriate IT system that would record operational events and allow the analysis of reliability and readiness.

\section{References}

1. Decyzja nr 435/MON Ministra Obrony Narodowej z dnia 24 grudnia 2013 r. w sprawie określenia funkcji gestorów $i$ centralnych organów logistycznych sprzętu wojskowego w resorcie obrony narodowej. 2013.

2. Loroch, L., Tomaszek, H. \& Żurek, J. Zarys metody oceny niezawodności i trwałości elementów konstrukcji lotniczych na podstawie opisu procesów destrukcyjnych in. Materiały XXXII Zimowej Szkoły Niezawodności (Szczyrk, 2004).

3. Loroch, L., Tomaszek, H. \& Żurek, J. Zarys metody określenia niezawodności urządzeń lotniczych w warunkach słabej korelacji zmian wartości parametrów diagnostycznych z nalotem statku powietrznego. Zagadnienia Eksploatacji Maszyn 39. ISSN: 0137-5474 (4 2004).

4. Migdalski, J. et al. Poradnik niezawodności. Podstawy matematyczne (ed Migdalski, J.) t. 1 (Wydawnictwo Przemysłu Maszynowego WEMA, Warszawa, 1982).

5. Niziński, S. \& Kupicz, W. Analysis of military motor vehicles operation processes. Zeszyty naukowe WSOWL 1, 216-223. ISSN: 1731-8157 (2011).

6. Przybysz, K. Dependability for the military vehicles in the safety aspects. Inżynieria Bezpieczeństwa Obiektów Antropogenicznych 1, 35-42. ISSN: 2450-1859 (2020).

7. Simiński, P. et al. Rozwój środków transportu w SZRP Praca zbiorowa (BEL Studio Sp. z. o. o., Warszawa, 2013).

8. Szczepanik, R., Tomaszek, H. \& Jasztal, M. Outline of the method of damage risk and fatigue life determination selected aircraft's elements in using condition, with use of Paris formula for m nequ 2. Zagadnienia Eksploatacji Maszyn 42, 99-110. ISSN: 0137-5474 (3 2007).

9. Tomaszek, H., Żurek, J. \& Jasztal, M. Models of catastrophic damage formation in aircraff's devices. Problemy eksploatacji 3, 193-202 (2005).

10. Tomaszek, H., Żurek, J. \& Jasztal, M. A method of estimating the risk of a catastrophic failure to engine's rotating members as related to fatigue - an outline. Journal of KONES Powertrain and Transport. Warsaw 14, 505-511 (2 2007).

11. Tomaszek, H., Żurek, J. \& Jasztal, M. Prognozowanie uszkodzeń zagrażajacych bezpieczeństwu lotów statków powietrznych ISBN: 8372046964 (Wydawnictwo Naukowe Instytutu Technologii Eksploatacji - PIB, Warszawa, 2008). 